particularly high values reaching 126 $\mathrm{mW} \mathrm{m} \mathrm{m}^{-2}$ and $143 \mathrm{~mW} \mathrm{~m}^{-2}$. Further to the south of the Solomon Islands, in the Coral Sea basin, heat flow reverts to normal (here about $62 \mathrm{~mW} \mathrm{~m}^{-2}$ ).

Generally speaking, heat flow in the vicinity of a trench-island arc system is about normal beneath the ocean basin adjacent to the trench, low in the trench region where lithosphere is descending, and above average on the continental side. The reason for the high heat flow behind arc-trench systems is still a matter of debate; but for the present purpose it is sufficient to know that it is a feature of island arcs clearly related in some way to the plate tectonic processes involved. In the Japan trench-arc system, for example, heat flow in the Japan Sea, the continental side of the system, averages $84 \mathrm{~mW} \mathrm{~m}^{-2}$ and that in the trench itself averages $29 \mathrm{~mW} \mathrm{~m}^{-2}$. These figures bear a notable resemblance to those from the Solomon Islands system. The only problem is that in the Solomon Islands case the heat flow values are reversed, being high in the trench side (although low in the trench itself) and low on the continental side. In other words, the heat flow data are apparently more consistent with the expected lithospheric downwelling from the Pacific side than with the actual descending of the lithosphere from the Australian side.

This is where the point about thermal inertia comes in. Halunen and Von Herzen argue that because of the Earth's high thermal inertia, the heat flow observed now (apart from the present trench) reflects not the current tectonic situation but that existing at some time in the past (probably the upper Miocene). Notwithstanding the apparent anomalous behaviour beneath the Solomon Islands region in the context of the western Pacific as a whole, the tectonic situation is, in fact, consistent with plate tectonics which shows that in the southwest Pacific the Australian plate is moving northwards and underthrusting the Pacific Ocean plate. The case now put forward by Halunen and Von Herzen, however, is that this is a comparatively recent development, and that at one time subduction took place from precisely the opposite (Pacific) direction in accord with the observed heat flow. They then go on to suggest that what reversed the flow was a particularly thick (about $40 \mathrm{~km}$ ) piece of spreading oceanic lithosphere which collided with the original island arc and, because of its buoyancy, effectively prevented further subduction from the Pacific direction. Because a continuation of lithospheric consumption was essential, subduction then began from the Australian plate. The crustal block which stopped the original subduction now largely forms the Ontong Java plateau which lies to the north of the Solomon Islands.
This model not only explains the observed heat flow but is also consistent with other geological and geophysical features of the region. For example, Coleman (Pacif. Sci., 24, 289; 1970) used structure and rock types to divide the Solomon Islands system into three linear geological provinces along the trend of the arc-the Pacific, central and volcanic (southwest) provinces. Of these, the central and volcanic provinces are typical of other western Pacific island arc systems. But the Pacific province is not, Coleman's conclusion being that it did not exist in its present position prior to the upper Miocene. To this, Halunen and Von Herzen add that the Pacific province is probably part of the Ontong Java plateau and thus did not assume its present position until about the time the subduction was reversed.

On the geophysical side, the shallow seismicity is, as would be expected, consistent with the present pattern of lithospheric motion. Shallow-earthquake epicentres lie along the south coasts of the Solomon Islands; and the distribution of intermediate foci suggests a subduction zone dipping at about $45^{\circ}$ to the northeast. But there is a gap in foci at depths of $225-380 \mathrm{~km}$ and the resumed deeper activity indicates an almost vertical focal plane. This suggests a detached slab of lithosphere at depth, although Halunen and Von Herzen propose that the slab may be not part of the present descending lithosphere but a remnant of the original Pacific subduction. The pattern of attenuation of short period $S$ waves is, as is usual in island arc systems, higher across the continental side and lower across the oceanic side; but, of course, since the subduction behaviour beneath the Solomon Islands is opposite from that of the western Pacific as a whole, the attenuation pattern is really more consistent with the original direction of subduction.

In conclusion, as Furumoto et al. (Pacif. Sci., 24, 315; 1970) demonstrated, the crust is indeed unusually thick (35$42 \mathrm{~km}$ ) beneath the Ontong Java plateau.

\title{
Magnetics East of the Lesser Antilles Arc
}

IN spite of the widespread attention given to oceanic magnetic anomalies in recent years, there are still many areas where anomalies are poorly defined, if at all. In some cases it is simply a question of waiting for somebody with sufficient resources to take an interest; but some of the regions remaining unstudied also present particularly difficult problems.

In the section of the Atlantic Ocean east of the Lesser Antilles island arc, for example, the magnetic pattern is complicated by the large number of fracture offsets, and the identification and correlation of lineations are made more difficult by a combination of slow spreading rate, relatively low anomaly amplitude and topographical influences. Nevertheless, in Nature Physical Science next Monday (October 29), Peter et al. are able to report that they have identified the whole Cainozoic magnetic anomaly pattern in the area, and conclude from it that the evolution of the corresponding section of the mid-Atlantic ridge was little different from that elsewhere in the north Atlantic.

This conclusion is based largely in a correlation of the magnetic anomalies and topography of the mid-Atlantic ridge east of the Lesser Antilles island arc with those of a standard ridge section between the Atlantis and Kane fracture zones in the north Atlantic. This correlation clearly shows that properties considered typical of the north Atlantic extend southward to the Vema fracture zone. Even so, some results were unexpected. For one thing, the offsets (dashed lines on the map) trend eastwest. Moreover, the continuity of lineations across the trend of the Barracuda ridge $\left(\mathrm{N} 108^{\circ} \mathrm{E}\right)$ suggests that this ridge is not part of a major transform fault but only a local feature. Similarly, although the southernmost of the three major fault troughs (hatched regions) coincides roughly with an offset and correlates with the east-west offset across the Researcher ridge, the two northerly troughs are not associated with magnetic offsets. The northerly troughs and parts of the ridges are thus probably the results of normal or reverse (rather than transform) faulting. North of the area of investigation, offsets do strike northwest-southeast, however, the change in direction probably occurring at about $19^{\circ} \mathrm{N}$ where the trend of the ridge crest also changes direction.

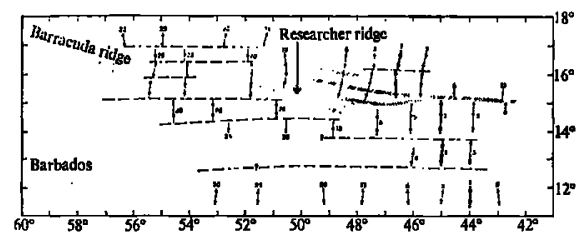

Finally, Peter et al. contend that their data support the view that since the upper Cretaceous North America and South America have moved away from Africa essentially as a single plate. They also propose a modification to the predrift reconstruction of the north Atlantic which would require a less severe rotation of the central American Palaeozoic blocks and allow for an east-west spreading of the mid-Atlantic ridge between Africa and the central American blocks from the upper Triassic to the lower Cretaceous. 